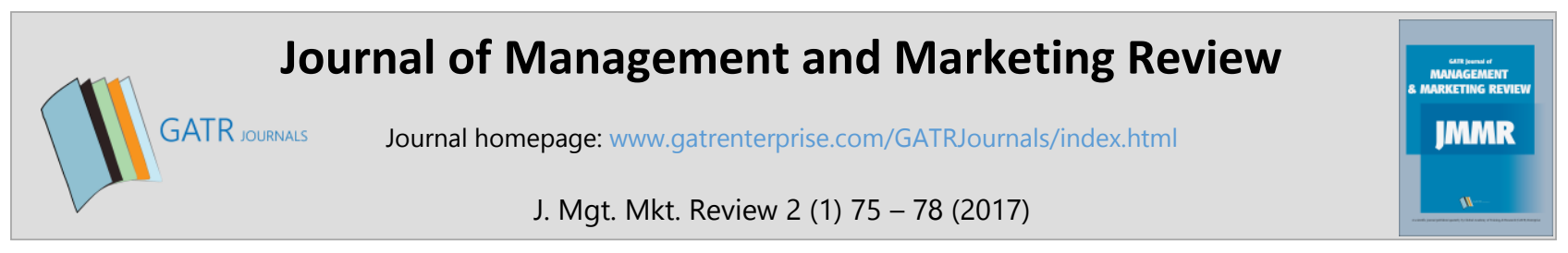

\title{
Analysis Performance Management System
}

\author{
Agatha Rinta Suhardi ${ }^{1 *}$ and Sakina Ichsani ${ }^{2}$ \\ 1,2 Faculty of Business and Management, Cikutra 204 A, 40125, Bandung, Indonesia
}

\begin{abstract}
Objective - Aggressive competition and globalization are characterized by the emergence of many new companies and technological advances. Many companies began to rearrange the strategy of competition in anticipation of free trade with a review of the objectives of strategic companies based on the needs of the international market, a comparison with companies that have the best performance in the world, as well as evaluating intense the internal competency of the company own. The key to winning this competition is through innovation. The goal of this paper is to analyze the factors that influence in the performance management system.

Methodology/Technique - Method in this research are performed by distributing questionnaires and respondents were given the opportunity to provide input to the company which then will researchers to convey to family companies that made the object of research.

Findings - Results show that there is correlation between the company's strategy, cross-functionality, market intelligence, employee motivation and company performance. There is correlation company's strategy and company performance, cross-functionally and company performance, market intelligence and company performance, the motivation of employees and company performance
\end{abstract}

Novelty - The study tries to test performance management of company.

Type of Paper: Empirical

Keywords: Analysis of Family Company; Cross-Functionality; Employee Motivation; Performance Management.

JEL Classification: L22, J53.

\section{Introduction}

Performance Management System has a closed cycle such as performance measurement, performance evaluation, diagnostic process, and follow-up of the diagnostic process. Innovation management is the implementation of an application, process, and a new management structure that represents an important beginning for the company to transform into a better direction (Mol \& Birkinshaw, 2006; Wibisono, 2006; Atkin \& Brooks, 2009; Suhardi, 2015). The process of innovation management is a process that is gradual and can be deployed. Management of innovation processes in progress for several years in their implementation.

\footnotetext{
* Paper Info: Received: January 6, 2017

Accepted: March 4, 2017

* Corresponding author:

E-mail: agatha.rinta@widyatama.ac.id

Affiliation: Faculty of Business and Management, Indonesia
} 
The management system has performance measurement, performance evaluation, diagnosis and follow-up of the process among stakeholders. Bacal (1998) reveal five basic views in the performance management system:

1. Integrative model for organizational performance. The structure of performance management as an integrative system of continuous mutual inter-aspects.

2. Focus on the process and results. Performance management into a system that not only resultsoriented. The process of becoming one of the aspects important support in the determination of good results.

3. The involvement of related parties in achieving the goals. Employed as the main subjects that perform business process organization directly, the involvement of emplooyee to support the achievement of organizational goals.

4. Assessment of objective performance and hit the target. Performance management includes objective performance assessment and compliance with the objectives of each part of the organization concerned.

5. Evaluation and learning between superiors and subordinates. Good performance management is able to provide a measurable performance evaluation results. The evaluation results can provide information between supervisors and subordinates.

Stages of performance management systems:

1. Performance evaluation is an assessment of performance compared with the plan or standards that have been agreed. At each performance measurement standards should be established as a means of achieving the review of an appeal which can be done internally and externally.

2. Diagnostic performance is a process to obtain the causes of the deviation of performance and find ways to achieve targeted performance. What is needed in the diagnostic of the cause of inaccuracy is getting the production, not just looking for possibilities.

3. Follow-up. There are two aspects of the remedial measures, technical and strategic aspects. Focus in the technical aspects are usually aimed at the short-term and focus on the strategic aspects of decisionmaking at the level of higher management and for the long term.

4. Maintain and keep technology advances. The performance management system is designed to be a dynamic and technology advances guarded against new developments, both related to changes in the environment of competition, government regulation, the demands of society, the development of customer needs, the latest technological developments.

\section{Method}

A method in this research are performed by distributing questionnaires and respondents were given the opportunity to provide input to the company which then will researchers to convey to family companies that made the object of research. During the research process, respondents who had accumulated 160 people. Respondents are employees or owners of the family company or institution in Bandung.

Variable in this research that the company's strategy (X1), cross-functionally (X2), market intelligence (X3), employee motivation (X4) and Company Performance (Y). Firstly we make descriptive analyze from all answer of the respondent to define which indicator can describe the problem to improvement the performance management. Then data will be processed through to looking for the coefficient of determination ( $\mathrm{r} 2$ ) to check whether there is a tendency early influence between independent and dependent variables, and how much is the influence. If the results of $\mathrm{r} 2$ are equal to zero, or near zero, maybe the tendency relationship is not linear. 


\section{Results}

From the results of the assessment of respondents to the variable corporate strategy, it can be concluded that the respondents rate the company always involve all stakeholders in the planning of the company, the company informs all parties agreed plan, the corporate culture is strong enough, the company has a good image in the eyes of employees, system procurement of raw materials companies are well integrated, seamless integration between parts are good, and the location of production adjacent to points of sale.

The result of the respondents assessment for variable cross-functionality, respondents gave the highest appraiser to employee relations are good. Results of assessment respondents to variable market intelligence illustrates that the highest ratings in a statement the selling price is determined based on the purchasing power of consumers, the company tried to reduce production costs in order to maintain the selling price, and the company implemented high standards for product quality.

The result of the respondents assessment for work motivation can be concluded that the highest ratings to the statement of managers capable of leading the subordinates and the owners of companies determine employees who will work in the company. The results of the respondents' assessment of corporate performance variables can be concluded that the highest ratings to a statement the company has high capital capabilities, the company is able to join / collaboration with other companies, and the company has a high productivity. This research can be described in the regression equation as:

$$
Y=7.581+0.068 X 1+0.416 X 2+0.517 X 3+0.204 X 4
$$

Where:

$\mathrm{Y}=$ Performance Company;

$\mathrm{X} 1$ = Corporate Strategy;

$\mathrm{X} 2$ = Cross-Functionality;

X3 = Market Intelligence;

$\mathrm{X} 4=$ Work Motivation.

\section{Discussion}

The problems arising in connection with this study is how much correlation the company's strategy, crossfunctionality, market intelligence, employee motivation and company performance. How much is correlation company's strategy and company performance? How much are correlation cross-functionally and company performance? How much are correlation market intelligence and company performance? How much is correlation the motivation of employees and company performance?

From the results of data processing obtained that determination coefficient of the company's strategy, crossfunctionality, market intelligence, employee motivation and company performance about $27 \%$. While the coefficient of determination between the Corporate Strategy and the Company Performance amounted to 7.8\%, Cross-Functionality and Company performance by $9.8 \%$, the Market Intelligence and Company Performance of $18.4 \%$, and work motivation to company performance about $10.6 \%$.

Some suggestions for companies that submitted by the respondents: increase professionalism and equality of opportunity for all employees, the company must make improvements overall because more competitors are emerging. Must be considered is the problem of coordination between departments should be better again, so there is no miscommunication. Improve the quality of human resources and planning in each program are made so that the output is continuous. The commitment was further enhanced in all sections and employees. Continue to develop human resources and science and technology in an era of tight competition. Provide guidance for the engineer to quickly in response to notification of any damage that is informed. Standardization of raw materials could soon be named. Create sales innovations such as online marketing. Follow the development of the market. The production site is less extensive for the production target. 


\section{Conclusion}

Generally, it can be said that the respondents rate the performance of their companies already have a good performance. There are many correlation between the company's strategy, cross-functionality, market intelligence, employee motivation and company performance. There is correlation company's strategy and company performance, cross-functionally and company performance, market intelligence and company performance, the motivation of employees and company performance.

\section{References}

Atkin, B., \& Brooks, A. (2009). Total facilities management. John Wiley \& Sons.

Bacal, R. (1998) Performance management. McGraw-Hill, New York.

Jay, H., Barry, R., \& Jagadeesh, R. (2009). Operations Management. Jakarta, Salemba Empat Publisher.

Mol, M. J., \& Birkinshaw, J. M. (2006). Against the flow: Reaping the rewards of management innovation. European Business Forum 27, 245-291

Suhardi, A. R. (2015). Renewal of Performance Management System in Family Company. Procedia-Behavioral and Sciences, vol. 211, pp. 448-454.

Wibisono, Dermawan (2006). Performance Management: Concepts, Design, and Engineering Improving the Competitiveness of Companies, Jakarta, Erlangga Publisher. 